\title{
Changes in adipose cells of Longissimus dorsi muscle in Iberian pigs raised under extensive conditions
}

\author{
DOLORES AYUSO ${ }^{1}$, ANA GONZÁLEZ ${ }^{2}$, FRANCISCO PEÑA ${ }^{2}$ and MERCEDES IZQUIERDO \\ ${ }^{1}$ Departament of Animal Production, Centro de Investigaciones Científicas y Tecnológicas de \\ Extremadura/CICYTEX, Ctra. A-V, Km 372, 06187 Guadajira, Badajoz, Spain \\ ${ }^{2}$ Department of Animal Production, University of Córdoba, Campus Rabanales, \\ Ctra. Madrid, Km 496, 14071 Córdoba, Andalusia, Spain
}

Manuscript received on July 27, 2015; accepted for publication on March 1, 2016

\begin{abstract}
Twenty-four Iberian castrated male pigs were used to characterize and evaluate the effect of the duration of "Montanera" in the adipocytes size and its relation with the backfat thickness and intramuscular fat. The animals were fed under extensive conditions during 30,60 and 90 days in the "Dehesa" before slaughtered. Carcass weight, percentage of intramuscular fat, thickness of backfat and its three layers and adipocytes size of the intramuscular fat were obtained. The group which expended 90 days on fattening obtained the highest adipocytes, with an area higher by a $50 \%$ than those that only expended 30 days. The differences in diameter and perimeter adipocyte were not as marked as area. A significant positive correlation between the diameter, area and perimeter of adipocyte with the backfat thickness were found. The fat cells in Iberian pig hypertrophy during the "montanera stage", being this increase significant from month to month in this period of fattening. Also, this adipocyte increase is correlated with the animal weight. The correlation between adipocyte size and inner layer of backfat shows that the inner layer obtained in live pig by ultrasound techniques could be a good marker of fat infiltration in pigs fattening in "montanera" system.
\end{abstract}

Key words: extensive, adipocyte, backfat thickness, intramuscular fat.

\section{INTRODUCTION}

Traditionally, the Iberian pig is raised under extensive system being fed with natural resources, acorns and grass, during the final fattening phase, called "Montanera". This stage occurs from October to March and there is a high weight gain and fat accumulation at intramuscular and dorsal level. This type of feeding, along with genetic factors and processing conditions of the products

Correspondence to: Dolores Ayuso Carrizosa

E-mail: lolayuso@gmail.com is responsible for the high quality of meat and meat products of the Iberian pig.

The traditional food system in the management seems to be influencing the quality of Iberian pig products (Ventanas et al. 2005). Besides the agro-silvo-pastoral system in which the Iberian pig breeding has a positive image for consumers to be associated with increased animal welfare, environmental impact reduction and protection of traditional production system (Rey et al. 2006).

The fat thickness is one of the most important carcass traits of pigs. The fat deposition has come 
to be one of the main objectives in improving pig production. Factors such as the size of the adipocyte (Etherton 1980, Hausman et al. 1983, Mersmann 1986) have been studied because it could explain the differences between lean and fatty pigs.

The development of adipose depots occur in three phases; the first one is characterized by a hyperplasia between 1 and 2 months old; the second one, between 2 and 5 months old, is based in both hyperplasia and hypertrophy; and in the last phase hypertrophy (Anderson et al. 1972, Henry 1977, Hood and Allen 1977).

Currently sufficient studies are made of the influence of type of feeding on carcass characteristics of Iberian pig, but there are few studies that examine as influences the duration of the Montanera in adipose tissue. Furthermore, while foreign breeds, mainly with a low-fat (Azain 2004, Domeneghini et al. 2006, Barnes et al. 2012) and high-fat (Hauser et al. 1997, Alfonso et al. 2005, Zhao et al. 2009, Nakajima et al. 2011) accumulation in their tissues, have been sufficiently studied as the fat of food is relationship with the adipocytes size of pigs. However, this fact has not been studied in Iberian pig. The difference in adipocyte size among breeds lean and fat, being higher in latter, is due to the genetic control of fat cells and affected by the backfat thickness (Nakajima et al. 2011), or a slow differentiation or lipid filling of adipose tissue cell in obese pigs, or to a later commitment to adipose differentiation (Hauser et al. 1997).

The feeding with food enriched in fat produces changes in performance as reducer intake, improved gain and feed efficiency and increases carcass fat (Azain 2004). This increase in carcass fat is correlated positively with the increase of adipocyte size (Steffen et al. 1978).

Therefore, the aim of this work is to characterize and evaluate the effect of the duration of "Montanera" in the adipocytes size in the Iberian pig and its relation with the backfat thickness and intramuscular fat.

\section{MATERIALS AND METHODS}

\section{DATA COLLECTION}

Twenty-four Iberian castrated male pigs of the Valdesequera line ("Valdesequera", Badajoz, Extremadura, Spain) progeny of four boars and twenty sows (two to three full siblings per litter) were used. Animals were randomly distributed into three groups of eight pigs each. The animals were fed under extensive conditions with acorn and grass during $30\left(\mathrm{M}_{30}\right), 60\left(\mathrm{M}_{60}\right)$, and $90\left(\mathrm{M}_{90}\right)$ days in the "Dehesa" before slaughtered. The animals were slaughtered with $463 \pm 3$ days of age, $484 \pm 2$ days of age and $504 \pm 2$ days of age for $\mathrm{M}_{30}, \mathrm{M}_{60}$ and $\mathrm{M}_{90}$ groups, respectively. The initial body weight (BW) was $128.88 \pm 5.46 \mathrm{~kg}, 129.25 \pm 4.83 \mathrm{~kg}$ and 128.38 $\pm 5.63 \mathrm{~kg}$, for $\mathrm{M}_{30}, \mathrm{M}_{60}$ and $\mathrm{M}_{90}$, respectively. Pigs were slaughtered at the pre-planned age (at 30, 60 and 90 days of fattening) and the final BW was $157.56 \pm 6.40 \mathrm{~kg}$ for $\mathrm{M}_{30}, 190.38 \pm 5.01 \mathrm{~kg}$ for $\mathrm{M}_{60}$ and $225.63 \pm 16.12 \mathrm{~kg}$ for $\mathrm{M}_{90}$.

\section{CARCASS TRAITS}

The carcass measurements as carcass weight, percentage of intramuscular fat and backfat thickness and its three layers were taken at the slaughterhouse. The traits of backfat were taken at two levels, tenth and fifteenth rib. For this purpose from each carcass a half portion of loin containing four chops (spanning from the $11^{\text {th }}$ to the $14^{\text {th }}$ ribs) was extracted, chilled and used to measure the total backfat thickness and its layers at the two already mentioned rib locations. The intramuscular fat content was quantified according the method described by Folch et al. (1957).

\section{ADIPOCYTE TRAITS}

Adipocytes size (area, diameter and perimeter) of the intramuscular fat of Longissimus dorsi muscle were obtained. For this purpose a $1 \mathrm{~cm}^{3}$ centered portion of the Longissimus dorsi muscle tissue was 
selected and placed in liquid nitrogen. After that, the samples were embedded in OCT medium and stored at $-80^{\circ} \mathrm{C}$ until further cutting. The sections of 20 micron thick, collected on slides with intervals between each cut 300 microns were performed using a Leica CM1900 cryostat. The sections were fixed in a solution of $2.5 \%$ glutaraldehyde in PBS for $10 \mathrm{~min}$, washed with PBS and then applied Oil Red O staining described by Lillie and Ashburn (1943). Using a digital camera coupled to a microscope Nikon Eclipse 90i photomicrographs were taken subsequently and analyzed by image analysis program (NIS-Elements RA). In each photograph the area, diameter and circumference of 1-12 adipocytes for each animal were obtained.

\section{STATISTICAL ANALYSIS}

The effect of the duration of fattening system called "Montanera" on the productive results, carcass traits and adipocytes size were studied by means of an analysis of covariance, using GLM procedure of Statistica 8.0 for windows. HSD Tukey's test was applied to compare the mean values. Mean values with standard deviation are reported. The correlations between carcass and adipocyte traits were investigated by Pearson's correlation analysis. Frequencies for adipocyte traits were obtained and represented graphically.

\section{RESULTS AND DISCUSSION}

Fat cells from adipose tissue of white pigs are closely studied by several groups of authors (Cagnazzo et al. 2006, Wimmers et al. 2007, Zheng and Mei 2009) that concluded that adipocyte size increases with live weight of animals. Other authors argue that the variation of the content of intramuscular and subcutaneous fat is closely related to changes in the size of adipocytes (Gondret and Lebret 2002, Alfonso et al. 2005, Barnes et al. 2012). In our study, the weight gain of Iberian pigs during the open range leads to increased adipocyte size in addition to observe also the intramuscular fat content was consistent with increase of adipocytes size (Table I). The $\mathrm{M}_{90}$ group obtained the highest adipocytes, with an area higher by a $50 \%$ than $\mathrm{M}_{30}$ group (26252.38 vs. $13693.49 \mu \mathrm{m}^{2}$ ). In the case of adipocyte diameter and perimeter the differences were not as marked as area, because it only increased by $26 \%$ between acorn-fed for three months and for a month (179.37 vs. 129.65 $\mu \mathrm{m}$ and 647.57 vs. $476.13 \mu \mathrm{m}$, respectively). Our results were higher than those obtained by Etherton and Allen (1979), Herpin et al. (1993), Smith et al. (1996), Hauser et al. (1997), Nünberg et al. (1998), Mourot (2001), Alfonso et al. (2005), Damon et al. (2006), Gardan et al. (2008), Zhao et al. (2009), Jiang et al. (2014), Szabó et al. (2010), Barnes et al. (2012), both in lean and obese breeds. Also, Nürnberget et al. (1998) affirmed that the rapid adipose tissue growth in pigs with 100-180 days of age is followed by a phase where adipocyte growth is minimal (180-220 days of age). In our case the pigs had more age (around one year) and there are no studies about growth of adipocyte in Iberian pigs, but if taken account studies in obese breeds as Meishan, shows that the growth in first months is more rapid than other months (Hauser et al. 1997).

In relation to the results obtained in commercial pig breeds, differences could be due to the weight of sacrifice (higher in our case) (Mourot 2001), as well as the genetics of the breed (Herpin et al. 1993, Hauser et al. 1997, Wood et al. 2004, Alfonso et al. 2005, Poulos and Hausman 2005).

The $45 \%$ of the adipocytes had an area situated in the range of 9000 to $15000 \mu \mathrm{m}^{2}$ in $\mathrm{M}_{30}$ group, of 15000 to $27000 \mu \mathrm{m}^{2}$ in $\mathrm{M}_{60}$ group and of 21000 to $33000 \mu \mathrm{m}^{2}$ in $\mathrm{M}_{90}$ group. In the case of perimeter in the range of 400 to $500 \mu \mathrm{m}$ are the $41 \%$ of the adipocytes measured in the $\mathrm{M}_{30}$ group, of 600 to $800 \mu \mathrm{m}$ in $\mathrm{M}_{60}$ group, and of 600 to $700 \mu \mathrm{m}$ in $\mathrm{M}_{90}$ group. In the last case, the diameter, the $55 \%$ of adipocytes range from 100 to $140 \mu \mathrm{m}$ in $\mathrm{M}_{30}$ group, from 100 to $160 \mu \mathrm{m}$ in $M_{60}$ group and from 160 
TABLE I

Effects of duration of fattening period (D) on carcass ${ }^{1}$ and adipocyte traits.

\begin{tabular}{|c|c|c|c|c|c|c|c|}
\hline & \multicolumn{6}{|c|}{ Duration of fattening ${ }^{2}$} & \multirow{3}{*}{$P$ values } \\
\hline & \multicolumn{2}{|c|}{$\mathbf{M}_{30}$} & \multicolumn{2}{|c|}{$M_{60}$} & \multicolumn{2}{|c|}{$M_{90}$} & \\
\hline & Mean & Std. & Mean & Std. & Mean & Std. & \\
\hline Body weight at start, kg & $128.9^{\mathrm{b}}$ & 5.5 & $129.2^{\mathrm{b}}$ & 4.8 & $128.4^{\mathrm{b}}$ & 5.6 & 0.95 \\
\hline Body weight at slaughter, $\mathrm{kg}$ & $157.6^{\mathrm{a}}$ & 6.4 & $190.4^{\mathrm{b}}$ & 5.0 & $225.6^{\mathrm{c}}$ & 16.1 & 0.00 \\
\hline Carcass weight, $\mathrm{kg}$ & $119.6^{\mathrm{b}}$ & 4.6 & $163.0^{\mathrm{c}}$ & 6.5 & $193.1^{\mathrm{d}}$ & 13.3 & 0.00 \\
\hline IFAT, $\mathrm{g} / 100 \mathrm{~g}$ & $2.74^{\mathrm{a}}$ & 1.25 & $4.72^{\mathrm{b}}$ & 1.41 & $6.22^{\mathrm{b}}$ & 2.45 & $\leq 0.01$ \\
\hline $\mathrm{BF} 10, \mathrm{~mm}$ & $7.26^{\mathrm{a}}$ & 0.75 & $9.90^{\mathrm{b}}$ & 0.43 & $10.94^{\mathrm{b}}$ & 1.98 & $\leq 0.01$ \\
\hline OBF10, mm & $1.57^{\mathrm{a}}$ & 0.23 & $2.00^{\mathrm{b}}$ & 0.25 & $1.87^{\mathrm{b}}$ & 0.34 & $\leq 0.01$ \\
\hline $\mathrm{MBF} 10, \mathrm{~mm}$ & $4.20^{\mathrm{a}}$ & 0.57 & $5.55^{\mathrm{b}}$ & 0.24 & $6.14^{\mathrm{b}}$ & 0.93 & $\leq 0.01$ \\
\hline IBF10, mm & $1.48^{\mathrm{a}}$ & 0.26 & $2.35^{\mathrm{b}}$ & 0.24 & $2.92^{\mathrm{b}}$ & 0.95 & $\leq 0.01$ \\
\hline $\mathrm{BF} 15, \mathrm{~mm}$ & $5.60^{\mathrm{a}}$ & 1.04 & $7.63^{\mathrm{b}}$ & 0.84 & $9.56^{\mathrm{c}}$ & 1.14 & $\leq 0.01$ \\
\hline OBF15, mm & $1.25^{\mathrm{a}}$ & 0.29 & $1.59^{\mathrm{b}}$ & 0.27 & $1.62^{\mathrm{b}}$ & 0.20 & $\leq 0.05$ \\
\hline $\mathrm{MBF} 15, \mathrm{~mm}$ & $2.51^{\mathrm{a}}$ & 0.61 & $3.62^{\mathrm{b}}$ & 0.45 & $3.92^{\mathrm{b}}$ & 0.63 & $\leq 0.01$ \\
\hline $\mathrm{IBF} 15, \mathrm{~mm}$ & $1.84^{\mathrm{a}}$ & 0.42 & $2.42^{\mathrm{a}}$ & 0.63 & $4.01^{\mathrm{b}}$ & 0.77 & $\leq 0.01$ \\
\hline Area, $\mu \mathrm{m}^{2}$ & $13693.49^{\mathrm{a}}$ & 3085.12 & $20273.92^{\mathrm{ab}}$ & 5558.03 & $26252.38^{\mathrm{b}}$ & 8429.56 & $\leq 0.01$ \\
\hline Perimeter, $\mu \mathrm{m}$ & $476.1^{\mathrm{a}}$ & 57.3 & $582.8^{\mathrm{ab}}$ & 95.4 & $647.6^{\mathrm{b}}$ & 95.8 & $\leq 0.01$ \\
\hline Diameter, $\mu \mathrm{m}$ & $129.6^{\mathrm{a}}$ & 15.0 & $157.6^{\mathrm{ab}}$ & 22.7 & $179.4^{\mathrm{b}}$ & 26.9 & $\leq 0.01$ \\
\hline
\end{tabular}

${ }^{1}$ IFAT: Intramuscular fat; BF10: Backfat thickness at tenth rib level; OBF10: Backfat thickness of outer layer at tenth rib level; MBF10: Backfat thickness of middle layer at tenth rib level; IBF10: Backfat thickness of inner layer at tenth rib level; BF15: Backfat thickness at fiftieth rib level; OBF15: Backfat thickness of outer layer at fiftieth rib level; MBF15: Backfat thickness of middle layer at fiftieth rib level; IBF15: Backfat thickness of inner layer at fiftieth rib level.

${ }^{2} \cdot \mathrm{M}_{30}=$ Thirty days on fattening; $\mathrm{M}_{60}=$ Sixty days on fattening; $\mathrm{M}_{90}=$ Ninety days on fattening.

to $220 \mu \mathrm{m}$ in $\mathrm{M}_{90}$ group (Fig. 1). The increase in adipocyte diameter is caused by the deposition of fat (Nürnberg and Wegner 1990).

Consistent with previous studies (Gondret and Lebret 2002, Alfonso et al. 2005, Velotto et al. 2012), a significant positive correlation between the diameter, area and perimeter of adipocyte with the backfat thickness were found (Table II), specifically with the inner layer taken at the $15^{\text {th }}$ rib (0.42, 0.40 and 0.36 , respectively). This correlation could be due to, and according with Fortin (1986), Geri et al. (1986), Barone et al. (2000) and Velotto et al. (2012), the adipocytes from inner layer are larger than the outer layer. Also, this inner layer of backfat (IBF15) has the most increase in size over "montanera" period of fattening, especially in the last section of fattening (Table I). In previous studies Ayuso et al. (2013) obtained a positive correlation between the inner layer thickness of backfat and intramuscular fat both in the carcass and in vivo by ultrasound methods $(0.47$ and 0.40 , respectively). The greater adipocyte size is the major contributing factor in the greater increase on backfat tissue in obese pigs (Nakajima et al. 2011).

There were significant differences in the amount of intramuscular fat during the fattening phase on "montanera" system. These differences appear to be due to an adipocyte hypertrophy and the increased size of these cells are positively correlated with the weight gain, intramuscular fat and the inner layer thickness of backfat at the $15^{\text {th }}$ rib level. The animals that spent 90 days on this system had higher deposits of intramuscular fat. The flavor, juiciness and tenderness of meat is variable and depends on fat content of meat (Fernandez et al. 1999, Brewer et al. 2001, Wood et al. 2004, Lonergan et al. 2007), due to this a specific development of intramuscular fat deposits is necessary (Hauser et al. 1997). Therefore, the animals that spend 90 days in fattening must present those carcasses with better organoleptic features. Zhao et al. (2009) suggested that fat pig breeds posses higher capacity to deposit 
TABLE II

Relationship between carcass traits ${ }^{1}$ and adipocyte traits.

\begin{tabular}{cccccccccc}
\hline & IFAT & BF10 & OBF10 & MBF10 & IBF10 & BF15 & OBF15 & MBF15 & IBF15 \\
\hline Area, $\mu \mathrm{m}$ & 0.07 & 0.12 & -0.01 & $0.21^{*}$ & 0.03 & $0.29^{*}$ & 0.08 & 0.05 & $0.40^{*}$ \\
Perimeter, $\mu \mathrm{m}$ & $0.14^{*}$ & 0.12 & -0.00 & $0.21^{*}$ & 0.03 & $0.31^{*}$ & 0.10 & 0.10 & $0.36^{*}$ \\
Diameter, $\mu \mathrm{m}$ & 0.11 & $0.17^{*}$ & -0.00 & $0.25^{*}$ & 0.08 & $0.33^{*}$ & 0.11 & 0.09 & $0.42^{*}$ \\
\hline
\end{tabular}

${ }^{1}$ IFAT: Intramuscular fat; BF10: Backfat thickness at tenth rib level; OBF10: Backfat thickness of outer layer at tenth rib level; MBF10: Backfat thickness of middle layer at tenth rib level; IBF10: Backfat thickness of inner layer at tenth rib level; BF15: Backfat thickness at fiftieth rib level; OBF15: Backfat thickness of outer layer at fiftieth rib level; MBF15: Backfat thickness of middle layer at fiftieth rib level; IBF15: Backfat thickness of inner layer at fiftieth rib level. * $P \leq 0.05$.

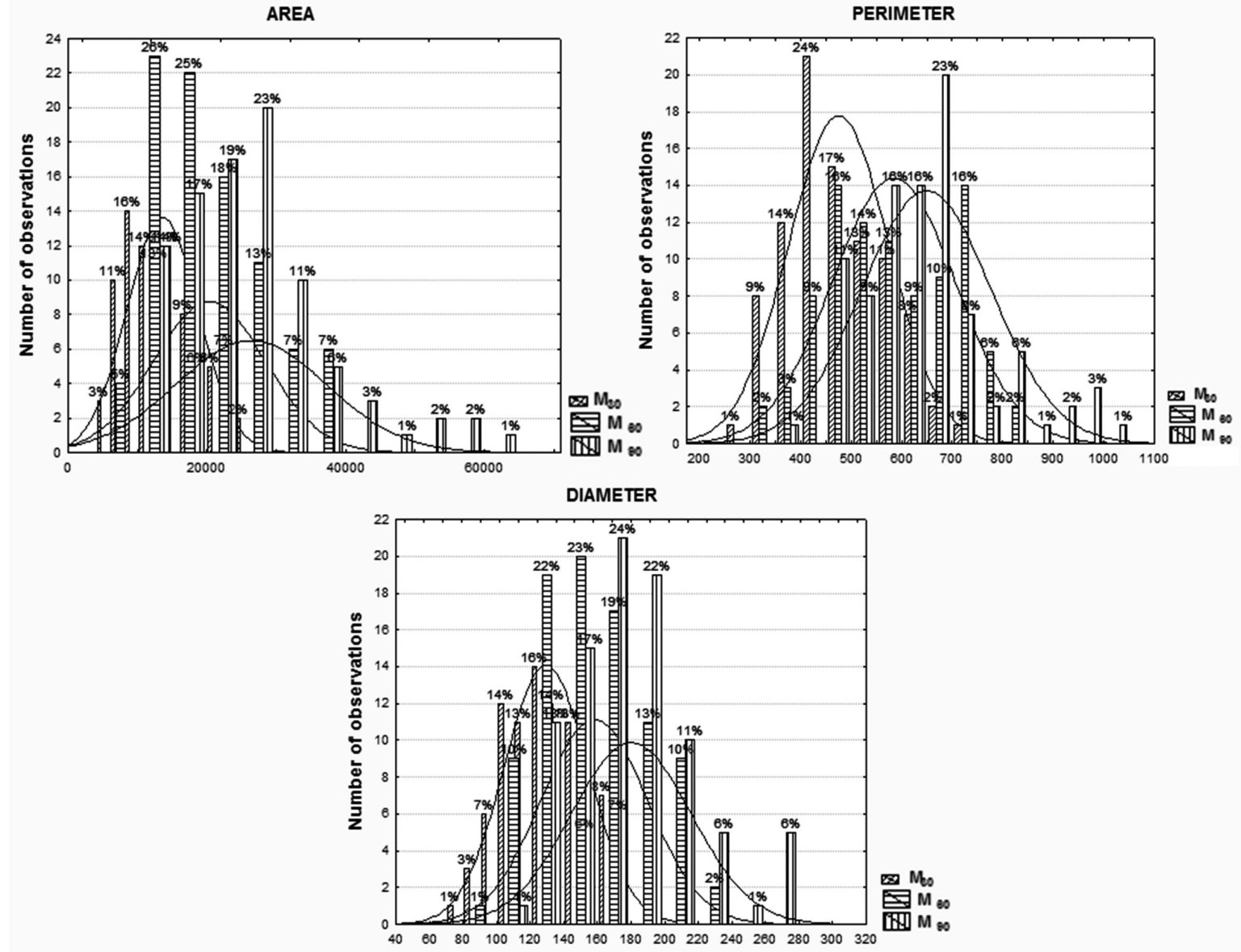

Figure 1 - Frequencies of adipocyte size traits from Iberian pigs. $M_{30}=$ Thirty days on fattening; $M_{60}=$ Sixty days on fattening; $M_{90}=$ Ninety days on fattening.

triacylglycerol in muscle deposit than lean pigs because intramuscular fat content is higher in first breeds ( 5.58 vs. $3.90 \%$ ). Also, higher intramuscular pigs appear to be because this kind of this breed has a high capacity of lypogenesis and fatty acid transport, lower potential of fat mobilization and fatty acid oxidation (Zhao et al. 2009). The increase in fat in pigs is associated with the increase of intramuscular fat adipose tissue. This increase is attributable to the larger increase in intramuscular adipocyte size (Barnes et al. 2012).

\section{CONCLUSIONS}

The fat cells in Iberian pig hypertrophy during the "montanera stage", being this increase significant from month to month in this period of fattening. 
Also, this adipocyte increase is correlated with the animal weight. Prolong the final fattening in "montanera stage" up to 90 days in Iberian pigs makes the marbling, and therefore the final quality of the meat is significantly higher than those animals with 60 or 30 days on "montanera" fattening and backfat is thicker. The correlation between adipocyte size and inner layer of backfat at $15^{\text {th }}$ ribs shows that the inner layer obtained in live pig by ultrasound techniques could be a good marker of fat infiltration in pigs fattening in "montanera" system.

\section{REFERENCES}

ALFONSO L, MOUROT J, INSAUSTI K, MENDIZABAL JA AND ARANA A. 2005. Comparative description of growth, fat deposition, carcass and meat quality characteristics of Basque and Large White pigs. Anim Res 54: 33-42.

ANDERSON DB, KAUFFMAN RG AND KASTERSCHMIDT LL. 1972. Lipogenic enzyme activities and cellularity of porcine adipose tissue from various anatomical locations. J Lipid Res 13: 593-599.

AYUSO D, GONZÁLEZ A, HERNÁNDEZ F, CORRAL JM AND IZQUIERDO M. 2013. Prediction of carcass composition, hams and forelegs weights and yields of Iberian pigs by using ultrasound measurements in live animals. J Anim Sci 91: 1884-1892.

AZAIN MJ. 2004. Role of fatty acids in adipocyte growth and development. J Anim Sci 82: 916-924.

BARNES KM, WINSLOW NR, SHELTON AG, HLUSKO KC AND AZAIN MJ. 2012. Effect of dietary conjugated linoleic acid on marbling and intramuscular adipocytes in pork. J Anim Sci 90: 1142-1149.

BARONE CMA, ESPOSITO I, OCCIDENTE M, ABBATIELLO M, CAPPUCCIO A AND MATASSINO D. 2000. Some aspects of meat production in pig autochthonous genetic types. III. Morphometric characteristics of fibre types and adipocytes. In: Almeida JA and Tirapicos Nunes J (Eds), Tradition and innovation in Mediterranean pig production. Zaragoza: CIHEAM Options Méditerranéennes: Série A. Séminaires Méditerranéens 41: 233-236.

BREWER MS, ZHU LG AND MCKEITH FK. 2001. Marbling effects on quality characteristics of pork loin chops: Consumer purchase intent, visual and sensory characteristics. Meat Sci 59: 153-163.

CAGNAZZO M, TE PAS MF, PRIEM J, DE WIT AA, POOL MH, DAVOLI R AND RUSSO V. 2006. Comparison of prenatal muscle tissue expression profiles of two pig breeds differing in muscle characteristics. J Anim Sci 84 $1-10$.

DAMON M, LOUVEAU I, LEFAUCHEUR L, LEBRET B, VINCENT A, LEROY P, SANCHEZ MP, HERPIN P AND GONDRET F. 2006. Number of intramuscular adipocytes and fatty acid binding protein- 4 content are significant indicators of intramuscular fat level in crossbred large white $\times$ Duroc pigs. J Anim Sci 84: 1083-1092.

DOMENEGHINI C, DI GIANCAMILLO A AND CORINO C. 2006. Conjugated linoleic acids (CLAs) and white adipose tissue: how both in vitro and in vivo studies tell the story of a relationship. Histol Histopathol 21: 663-672.

ETHERTON TD. 1980. Subcutaneous adipose tissue cellularity of swine with different propensities for adipose tissue growth. Growth 44: 182-191.

ETHERTON TD AND ALLEN CE. 1979. Metabolic Responsiveness of Different Size Adipocytes to Fasting and Refeeding in the Pig. J Nutr 110: 1169-1175.

FERNANDEZ X, MONIN G, TALMANT A, MOUROT J AND LEBRET B. 1999. Influence of intramuscular fat content on the quality of pig meat-1, Composition of the lipid fraction and sensory characteristics of $m$. longissimus lumborum. Meat Sci 53: 59-65.

FOLCH J, LEES M AND SLOANE STANLEY GH. 1957. A simple method for the isolation and purification of total lipides from animal tissues. J Biolog Chem 226: 497-509.

FORTIN A. 1986. Development of backfat and individual fat layers in the pig and its relationship with carcass lean. Meat Sci 18: 255-270.

GARDAN D, GONDRET F, VAN DEN MAAGDENBERG K, BUYSC N, DE SMETB S AND LOUVEAU I. 2008. Lipid metabolism and cellular features of skeletal muscle and subcutaneous adipose tissue in pigs differing in IGF-II genotype. Domest Anim Endocrinol 34: 45-53.

GERI G, ZAPPA A AND FRANCI O. 1986. Influenza dello sviluppo corporeo e della localizzazione sulla cellularità del tessuto adiposo nei suini. Zoot Nutr Anim 12: 9-24.

GONDRET F AND LEBRET B. 2002. Feeding intensity and dietary protein level affect adipocyte cellularity and lipogenic capacity of muscle homogenates in growing pigs, without modification of the expression of sterol regulatory element binding protein. J Anim Sci 80: 3184-3193.

HAUSER N, MOUROT J, DE CLERCQ L, GENART C AND REMACLE C. 1997. The cellularity of developing adipose tissues in Pietrain and Meishan pigs. Reprod Nutr Dev 37: 617-625.

HAUSMAN GJ, CAMPION DR AND THOMAS GB. 1983. Adipose tissue cellularity and histochemistry in fetal swine as affected by genetic selection for high or low backfat. J Lipid Res 24: 223-228.

HENRY Y. 1977. Developpement morphologique et metabolique du tissu adipeux chez le porc, influence de 
la sèlection de I'alimentation et du mode d'elevage. Ann Biol Anim Biochem Biophys 17: 923-952.

HERPIN P, LE DIVIDICH J AND AMARAL N. 1993. Effect of selection for lean tissue growth on body composition and physiological state of the pig at birth. J Anim Sci 71: 2645-2653.

HOOD RL AND ALLEN CE. 1977. Cellularity of porcine adipose tissue: effects of growth and adiposity. J Lipid Res 18: 275-284

JIANG AA, LI MZ, LIU HF, BAI L, XIAO J AND LI XW. 2014. Higher expression of acyl-CoA dehydrogenase genes in adipose tissues of obese compared to lean pig breeds. Genet Mol Res 13: 1684-1689.

LILLIE RD AND ASHBURN LL. 1943. Supersaturated solutions of fat stains in dilute isopropanol for demonstration of acute fatty degeneration not shown by Herxheimer's technique. Arch Pathol 36: 432-440.

LONERGAN SM, STALDER KJ, HUFF-LONERGAN E, KNIGHT TJ, GOODWIN RN, PRUSA KJ AND BEITZ DC. 2007. Influence of lipid content on pork sensory quality within $\mathrm{pH}$ classification. J Anim Sci 85: 10741079.

MERSMANN HJ. 1986. Postnatal expression of adipose tissue metabolic activity associated with a porcine genetic obesity. J Anim Sci 63: 741-746.

MOUROT J. 2001. Mise en place des tissus adipeux souscutanés et intramusculaires et facteurs de variation quantitatifs et qualitatifs chez le porc. INRA Prod Anim 14: 355-363.

NAKAJIMA I, OE M, OJIMA K, MUROYA S, SHIBATA M AND CHIKUNI K. 2011. Cellularity of developing subcutaneous adipose tissue in Landrace and Meishan pigs: Adipocyte size differences between two breeds. Anim Sci J 82: 144-149.

NÜRNBERG K AND WEGNER J. 1990. Fatty acid composition and adipocyte diameter of backfat in boars during growth. Arch Tierz 34: 51-56.

NÜRNBERG K, WEGNER J AND ENDER K. 1998. Factors influencing fat composition in muscle and adipose tissue of farm animals. Liv Prod Sci 56: 145-156.

POULOS S AND HAUSMAN G. 2005. Intramuscular adipocytes-potential to prevent lipotoxicity in skeletal muscle. Adipocytes 1: 79-94.
REY AI, DAZA A, LÓPEZ-CARRASCO C AND LÓPEZBOTE CJ. 2006. Feeding Iberian pigs with acorns and grass in either free-range or confinement affects the carcass characteristics and fatty acids and tocopherols accumulation in Longissimus dorsi muscle and backfat. Meat Sci 73: 66-74.

SMITH DR, KNABE DA AND SMITH SB. 1996. Depression of lipogenesis in swine adipose tissue by specific dietary fatty acids. J Anim Sci 74: 975-983.

STEFFEN DG, CHAI EY, BROWN LL AND MERSMANN HJ. 1978. Effects of diet on swine glyceride lipid metabolism. J Nutr 108: 911-918.

SZABÓ A, VISKI A, EGYHÁZI Z, HÁZAS Z, HORN P AND ROMVÁRI R. 2010. Comparison of Mangalica and Hungarian Large White pigs at identical bodyweight: 1 . Backfat histology. Arch Tierz 53: 141-146.

VELOTTO S, VITALE C AND CRASTO A. 2012. Muscle fibre types, fat deposition and fatty acid profile of Casertana versus Large White pig. Anim Sci Pap Rep 30: 35-44.

VENTANAS S, VENTANAS J, RUIZ J AND ESTÉVEZ M. 2005. Iberian pigs for the development of high-quality cured products. In: Recent Developments in Agricultural and Food Chemistry, Singpost, Trivandrum, India, p. 2753.

WIMMERS K ET AL. 2007. Associations of functional candidate genes derived from gene-expression profiles of prenatal porcine muscle tissue with meat quality and muscle deposition. Anim Genet 38: 474-484.

WOOD JD, NUTE GR, RICHARDSON RI, WHITTINGTON FM, SOUTHWOOD O, PLASTOW G, MANSBRIDGE R, DA COSTA N AND CHANG KC. 2004. Effects of breed diet and muscle on fat deposition and eating quality in pigs. Meat Sci 67: 651-667.

ZHAO SM, REN LJ, CHEN L, ZHANG X, CHENG ML, LI WZ, ZHANG YY AND GAO SZ. 2009. Differential expression of lipid metabolism related genes in porcine muscle tissue leading to different intramuscular fat deposition. Lipids 44: 1029-1037.

ZHENG GS AND MEI ZS. 2009. Physiology, affecting factors and strategies for control of Pig meat intramuscular Fat. Recent Pat Food Nutr Agric 1: 59-74. 